\title{
Определение содержания стероидных гликоалкалоидов соланина и хаконина в диких видах картофеля методом ВЭЖХ
}

Домрачев Д.В. ${ }^{l *}$, м.н.с., Иванова К.А. ${ }^{2}$, Колошина К.A. ${ }^{2}$, Герасимова С.B. ${ }^{2}$ ${ }^{I}$ ФГБУН Новосибирский институт органической химии им. Н.Н. Ворожиова СО РАН, Новосибирск, Россия;

${ }^{2}$ ФИЦ Институт иитологии и генетики СО РАН, Новосибирск, Россия. *e-mail:dmitry@nioch.nsc.ru

Подобраны условия для извлечения из надземной части растения стероидных гликоалкалоидов и количественного определения содержания соланина и хаконина методом ВЭЖХ. С использованием полученной методики охарактеризовано содержание соланина и хаконина в 13 дикорастущих видах картофеля из коллекции ВИР, воспроизведенных в вегетачионных условиях региона.

Ключевые слова: Solanuт, гликоалкалоиды, соланин, хаконин, ВЭЖХ.

\section{Steroidal glycoalkaloids solanine and chaconine determination by HPLC in potato wild species}

Domrachev Dmitry Vasilievich, $N$. N. Vorozhtsov Novosibirsk Institute of Organic Chemistry Of the Siberian Branch of Russian Academy of Science, Novosibirsk, Russia.

The conditions were selected for the extraction of steroidal glycoalkaloids from the aerial part of the plant and the quantitative determination of the content of solanine and chaconine was made by HPLC. Using the obtained method, the content of solanine and chaconine in 13 wild potato species from the VIR collection, reproduced under the growing conditions of the region, was characterized

Key words: Solanum, glycoalkaloids, solanine, chaconin, HPLC.

Одной из важнейших характеристик хозяйственных растений является содержание вторичных метаболитов, в том числе и такого важного класса соединений, как алкалоиды. Для картофеля (Solanum tuberosum) важно контролировать содержание гликоалкалкалоидов соланина и хаконина [1]. Содержание гликоалкалоидов в дикорастущих видах картофеля изучено гораздо меньше. Так, показано, например, что, кроме соланина и хаконина, в диких видах присутствуют и другие гликоалкалоиды [2].

Дикие виды картофеля могут быть введены в селекционную работу для придания полезных признаков, таких как устойчивость к болезням и вредителям [3, 4]. Вместе с тем необходимо контролировать, чтобы вредные признаки, присущие диким видам, как, например, высокое содержание 
гликоалкалоидов, не передались культурным [5].

В нашей работе мы изучали содержание гликоалкалоидов в видах Solanum из коллекции ВИР, воспроизведенных в вегетационных условиях региона: S. demissum Lindl., S. polyadenium Greenm., S. pinnatisectum Dun., S. ehrenbergii Bitt., S. stoloniferum Schlechtd., S. jamesii Torr., S. tarijense Hawkes, S. cardiophyllum Lindl., S. pinnatisectum Dun., S. dolichostigma Buk., S. fendleri A. Gray S. kurtzianum Bitt. et Wittm. Ex Engl, S. chacoense Bitter.

Растения выращивались на полях СибНИИРС (Россия, Новосибирская область) в парнике, обтянутом укрывным материалом, пропускающим свет, влагу и воздух, но задерживающим насекомых и пыльцу других растений. Растения, выращенные in vitro в трех повторностях, высаживали в 12 л ведра с землей «TERRA VITA, питательный грунт универсальный», смешанной в равных пропорциях с естественным грунтом, добытым из-под дерна в березовой роще. Урожай собирали в период сбора урожая культурного картофеля. Надземную часть сушили до воздушно-сухого состояния и измельчали.

Измельченное и высушенное сырье в количестве 0.2-2 грамма экстрагировали 24-48 часов при комнатной температуре. Состав экстрагента: $40 \%$ метанола $+5 \% \mathrm{CH}_{3} \mathrm{COOH}+55 \%$ воды, из полученного экстракта отбирали аликвоту 1 мл, фильтровали через шприц-фильтр пористостью 0,45 мкм и использовали для анализа. Анализ проводился на обращенно-фазовой колонке ZORBAX-SB-C18, элюент 0,1 \% $\mathrm{CF}_{3} \mathrm{COOH}$ (А) и ацетонитрил (B). 0 10 мин $80 \%$ A + $20 \%$ B, 10-20 мин градиент до $100 \%$ В, детектирование на длине волны 205 нм. Калибровка осуществлялась путем анализа стандартных образцов соланина и хаконина (SigmaAldrich).

Наибольшее содержание соланина и хаконина $(25,7$ мг/г воздушносухого сырья (2,57 \% масс)) выявлено в Solanum dolichostigma Buk. Bce прочие образцы содержат гликоалкалоиды в существенно меньших количествах: S. pinnatisectum Dun - 1,8 мг/Г (преимущественно хаконин), S. polyadenium Greenm. - 1,7 мг/г (преимущественно хаконин), S. stoloniferum Schlechtd. - 0.5 мг/г (преимущественно хаконин).

Bсе прочие образцы содержат соланина и хаконина менее $0,5 \mathrm{Mг} / \Gamma$ (типичное для надземной части Solanum tuberosum содержание суммарных гликоалкалоидов), однако содержат, по-видимому, другие гликоалкалоиды.

Благодарности: Работа выполнена при финансовой поддержке гранта РФФИ № 18-316-00068.

\section{Список литературы}

1. Friedman M. Potato glycoalkaloids and metabolites: roles in the plant and in the diet // Journal of Agricultural and Food Chemistry. - 2006. - T. 54. - №. 23. - C. 8655-8681.

2. Friedman M., McDonald G. M., Filadelfi-Keszi M. A. Potato glycoalkaloids: chemistry, analysis, safety, and plant physiology //Critical Reviews in Plant Sciences. 1997. - T. 16. - №. 1. - C. 55-132. 
3. Зотеева Н.М., Зимнох-Гузовска Е. Влияние генотипов картофеля на патогенные свойства Phytophthora infestans //Микология и фитопатология. - 2005. T. 39. - №. 1. - С. 59-65.

4. Чалая Н.А., Бирюкова В.А., Киру С.Д. Новые источники устойчивости к золотистой картофельной нематоде (G. rostochiensis Woll.) из коллекции дикорастущих видов картофеля ВИР //Известия Санкт-Петербургского государственного аграрного университета. - 2012. - №. 26. - С. 45-50.

5. Laurila J. et al. Formation of parental-type and novel glycoalkaloids in somatic hybrids between Solanum brevidens and S. tuberosum //Plant Science. - 1996. - T. 118. №. 2. - C. 145-155.

DOI 10.18699/GPB2020-26

\section{Особенности накопления биофлавоноидов в ягодах интродуцированных сортов винограда на Алтае}

Ериова И.В., к.б.н., доиент, в.н.с., зав. лабораторией индустриальных технологий, отдел «НИИСС», ФГБНУ Федеральный Алтайский научный иуентр агробиотехнологий, г. Барнаул, Россия.

e-mail:inessers@yandex.ru

В статье представлены результаты исследования содержания биофлавоноидов в ягодах интродуцчированных на Алтае сортов винограда. Установлены суммарное содержание флавоноидов и количество отдельных фракций, зависимость этих показателей от метеоусловий года. Выделень сорта - ценные источники биоантиоксидантов.

Ключевые слова: виноград, сорта, ягоды, биофлавоноиды.

The particularities of bioflavonoid accumulation in the berries of grape varieties introduced in the Altai region

Ershova I.V. Federal Altai Scientific Centre of Agro-Biotechnologies, Barnaul, Russia.

The article discusses the results of the research of bioflavonoid content in the fruits of grape varieties introduced in the Altai region. The total content of flavonoids and the number of separate flavonoid fractions is determined, as well as dependence of these values on weather conditions of the year. The varieties that represent a valuable source of bio-antioxidants are also determined.

Key words: grape, varieties, berries, bioflavonoids.

Ягоды винограда, одной из самых распространенных культур в мире, по праву считаются высокоценным лечебным продуктом питания, сырьем 